\title{
The Feminist Saga: A Risk or an Opportunity for Indonesian Womenpreneur Towards Feminist Attitude in Twitter?
}

\author{
Irmawan Rahyadi ${ }^{1}$, Enny Khurniasari ${ }^{2}$ \\ \{irmawan.rahyadi@binus.edu ${ }^{1}$ \} \\ Communication Department, BINUS Graduate Program, Master of Strategic Marketing \\ Communication, Bina Nusantara University, Jakarta, Indonesia ${ }^{1,2}$
}

\begin{abstract}
Performance of the social media communication system can be analyzed by creating suitable digital method approach, measurement, and models. The communication perspectives are shown by utilizing features in Twitter conversation and navigation system and image-based measurements together. This study report on the findings about the practical use of Twitter in womenpreneur accounts in Indonesia to reveal their interpretation and image production of Feminist concept. A digital method approach to womenpreneur Twitter accounts is obtained. The data is qualitatively analyzed in relations to feminism concept. These are integrated to obtain communication data more accurately for the Feminism concept. It shows color scheme, topic, and event organizing as channel to interpret concept of feminism. In addition, the importance of gender is used to support the attitude information of the communication. Feminine image and relatable topics were key contributors to their own interpretation of the concept of feminism. The results advocate for a more nuanced understanding of the relation between social media conversation and social media users, as indications of awareness of feminism discipline.
\end{abstract}

Keywords: Feminist saga, Womenpreneur, Twitter

\section{Introduction}

"I was raised to be an independent woman, not the victim of anything. If we do not lift up women and families, everyone will fall short" [1]. The quote is taken from one of the favorite quotes circling the Internet after Kamala Harris was elected as the first female vice president of the United States of America. Some people look at her important role in one of the powerful countries in the world from her racial background [2], [3], but some feminism activists and supporters praised her accomplishment [4].

While feminism focus on the gender issue, most of the attitude and identity of feminist is not only concentrated on the issue but it widens to the area of political ideology, sexuality, and social justice [5]. Feminism has been at the heart of modern development where it is spread beyond western countries. Countries in Asia, for example, perceived feminism as western ideology and addressed it within their local context [6].

One of the identities and attitudes within the concept of feminism is gender equality. It refers to how women make social and political playing field at the same level. This fact turns into feminist resistance where women ask for more opportunity or make their own way to explore opportunities within their community [7]. Education, job, public facility, political role, 
and technological access are some of the social and political ranges where feminism asks to be equal despite gender difference.

Making a living in the competitive environment narrows job opportunities with increasingly higher number of job applicant to job openings. Some society even make this competition even harder in the perspective of gender background [8]. Looking at this level of competitiveness, people look towards entrepreneur prospect. This study aims to look at the concept of feminism within women entrepreneur in Indonesia.

The concept brings identity and attitude guiding their communication style. The terms women entrepreneur known as womenpreneur after the Global Entrepreneur Summit [9]. Their communication style reflects some identity in the message they choose, and this study explore a specific social media communication to reveal the concept feminism representation within the platform.

\section{Method}

Three accounts associated with the womenpreneur spirit in Indonesia were discussed in this study. Each provided digital data as primary data which were covering conversation and navigation system and image-based measurements in Twitter platform. A digital method approach was implemented for this study. A digital method approach mostly done using software but only just a browser would be considered digital method [10]. This study employed features from Twitter web-based access. Four thousand two hundred and twenty-two tweets were identified and analyzed. The number of tweets came from three community accounts which focus and promote womenpreneur ideas in Indonesia. They are @ womenpreneuridn, @womanpreneurcom and @DeDasterpreneur. The reason behind the selection of the three accounts is because they are using the idea name as the focus of this study as well as the idea that they are promote using their accounts. All accounts had directly showed the concept of celebrating the womenpreneur by posting the idea in the field of business and not from universal gender perspectives.

The data from the accounts, which are categorized in a communication pattern, analyzed using elements in Feminist concept and theory. There is a choice of message and deliverance as well as type of images that had examined in the data analysis step. Each data represented a certain public representation to the followers and the general Twitter users. The data is taken from their accounts which can be accessed publicly. Some of the posting also in the form of retweets where the accounts only reposted some tweets from other Twitter accounts without any comment. The total postings in the three accounts were explored from their first posting until the beginning of November 2020. The three accounts were chosen because the relatively decent number of engagements to help the data gathering process where data is important to reveal the Twitter communication strategy and pattern in Feminist concept presence.

\section{Results and Discussion}

This Result and discussion derived from the data present in categories as findings in this study which will be explained below. 


\subsection{Community not individual}

Representation in Twitter conversation shows that identity is clearly defined as women who conduct a kind of entrepreneurship. Twitter has been a place where entrepreneur get information, inspiration and motivation [11]. The three Twitter accounts are organization or to be precise community. Their communication as a community reflects not only one female individual, but a group of females joined in an agreement to certain identity and attitude.

The first data is from womenpreneuridn. They have communicated in Twitter with their official account since 2018. Getting their identity from the names is obvious hence, their choice of the color in their logo tend to use pink which associated with feminism element. Figure 1 shows the color choice but not really reflect the mission of the account in the profile picture. Interpreting from their bio which says," Empowering Indonesia Womenpreneur makes this study chose this account as the data. The number of tweets posted by this account within the data gathering period contains motivational quotes and events publication. Users in Twitter proven to follow brand or personality that similar with their own character [12], therefore the motivational quotes in particular aim to attract like-minded who appreciate the specific quotes. The quotes contained in this Twitter account empowered women to learn, step-up, be grateful, take risks, etc. The tweets that covered quotes unfortunately only text-based tweets. Motivational-quote tweets in a form of image or animated tweet represents stronger and more interesting contents [13].

They show good networking with entrepreneur community with the guest they invited in their events. For example, they invited Wanda Ponika as one of the successful womenpreneurs in Indonesia. They also invited Sandiaga Uno, a former vice president candidate and successful entrepreneur for one of their events. Networking value in Twitter mirrors how this account manages to maximize features provided by Twitter to inform, entertain, motivate audiences that follow or come across their tweets [14].

Within the posts, they promoted the strength of women in entrepreneurship as the bio and name of the account stated. Motivating women in Indonesia and even organized events and facility (such as coaching and seminar) for women to be entrepreneur. Intrinsic motivation has a significant role in Twitter usage as many users looking for motivation in this platform [15].

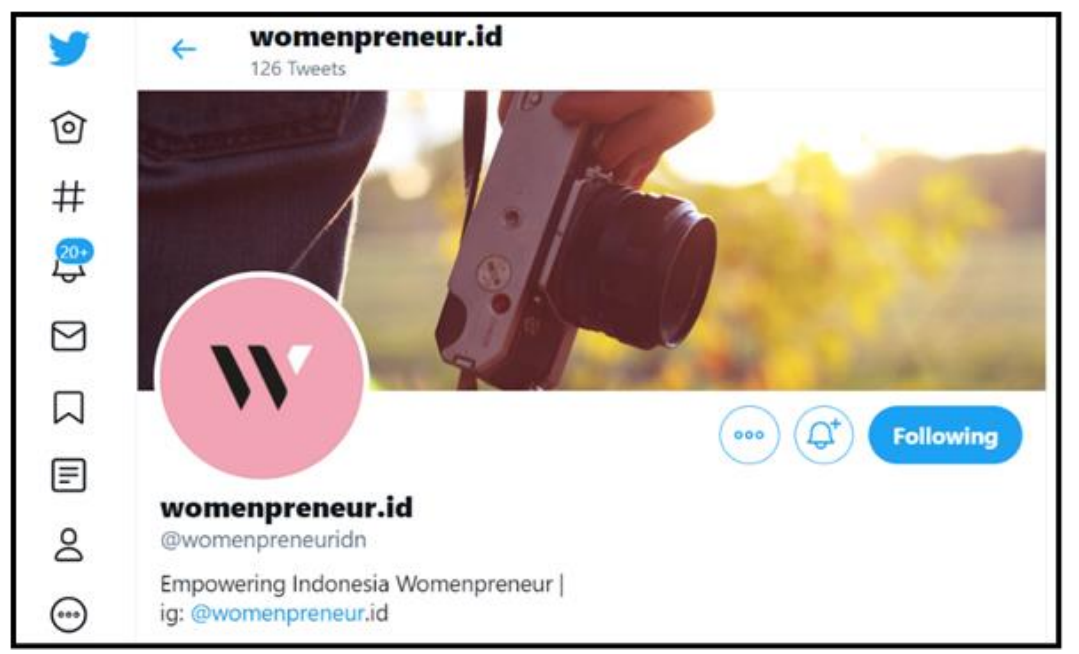

Fig. 1. Womenpreneur.id 
The next account that shows the identity of feminism in the area of entrepreneurship in Indonesia is DeDasterpreneur. They name implies daster in Indonesian which mean a dress. So, the username clearly targets women, and the full name of the account is Wanita Pengusaha which literally means womenpreneur. This account looks less formal than the previous one because of their choice of name and the bio, "walopun dasteran, mendidik \& memantau perkembangan anak, sambal masak lauk favorite keluarga tapi INCOME teteup mengalir DERAS, mau?" "Even though in our dress, educating \& monitoring the development of our child, while cooking our family's favorite dish but the income still flows swiftly, want to know more?". Figure 2 shows that profile picture in this account reflects women identity with closeup photo of a face of smiling woman. Workshop, conference, speech, and competition are some of the messages their posted in the tweets. Informing the niche community practiced by this account and the accounts alike underlining events such as workshop as product of information within the community [16]. The reposting tweets from some of their networking users and external events organizer is recorded from their account. The color scheme does not show any identity of feminism but profile picture and header banner show women picture and drawing.

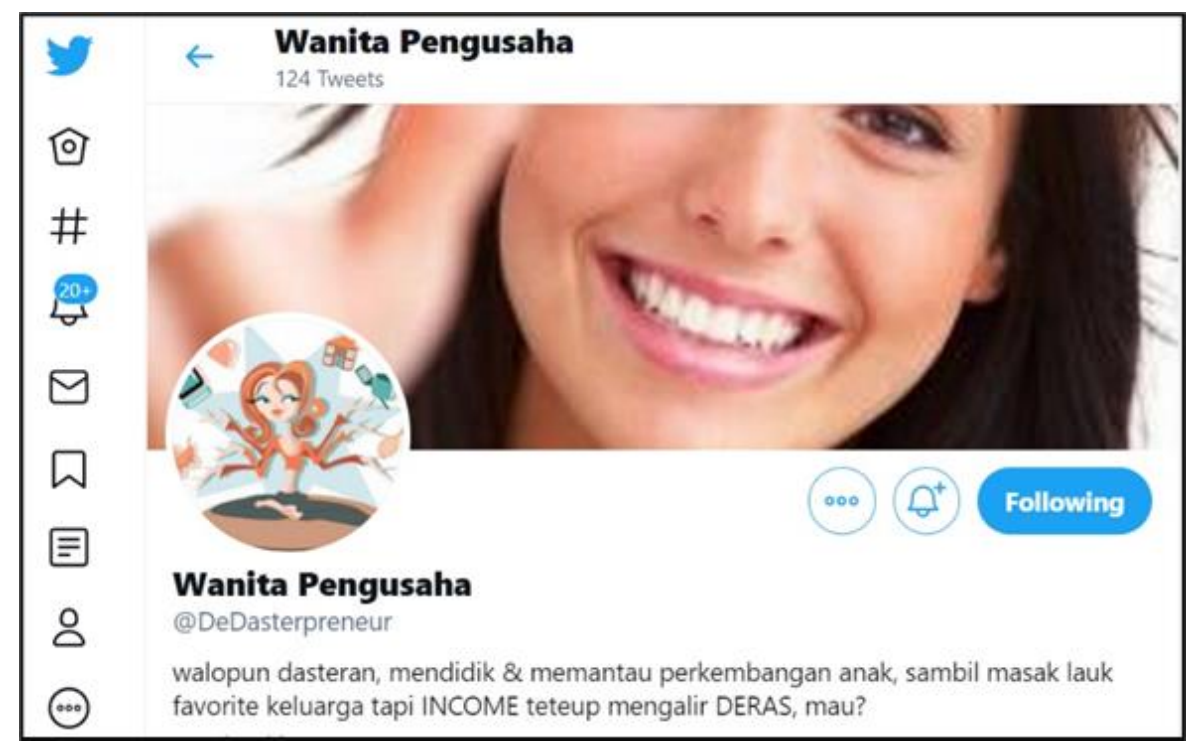

Fig. 2. DeDasterpreneur

The last account that has been explored in this study is womanpreneurcom. The bio clearly stated their mission. It says, "Karya Perempuan Indonesia- Womanpreneur Community. Wadah perempuan jadi womanpreneur Tangguh \& Kreatif." While Twitter is a proven social media platform to support community [17], this account mission is not only limited to Twitter but also active in their own website.

A place for women to be tough \& creative womanpreneurs". Looking at their posts, which is the highest among the other, the retweets show their exposure from the national mass media where they attend and promote the idea and mission. The logo and header banner show the settle color scheme which refers to feminist tone. Figure 3 shows that this account only uses their logo for their profile picture. This account also posted their social contribution such as when they donated money to health workers during the pandemic Covid-19. 


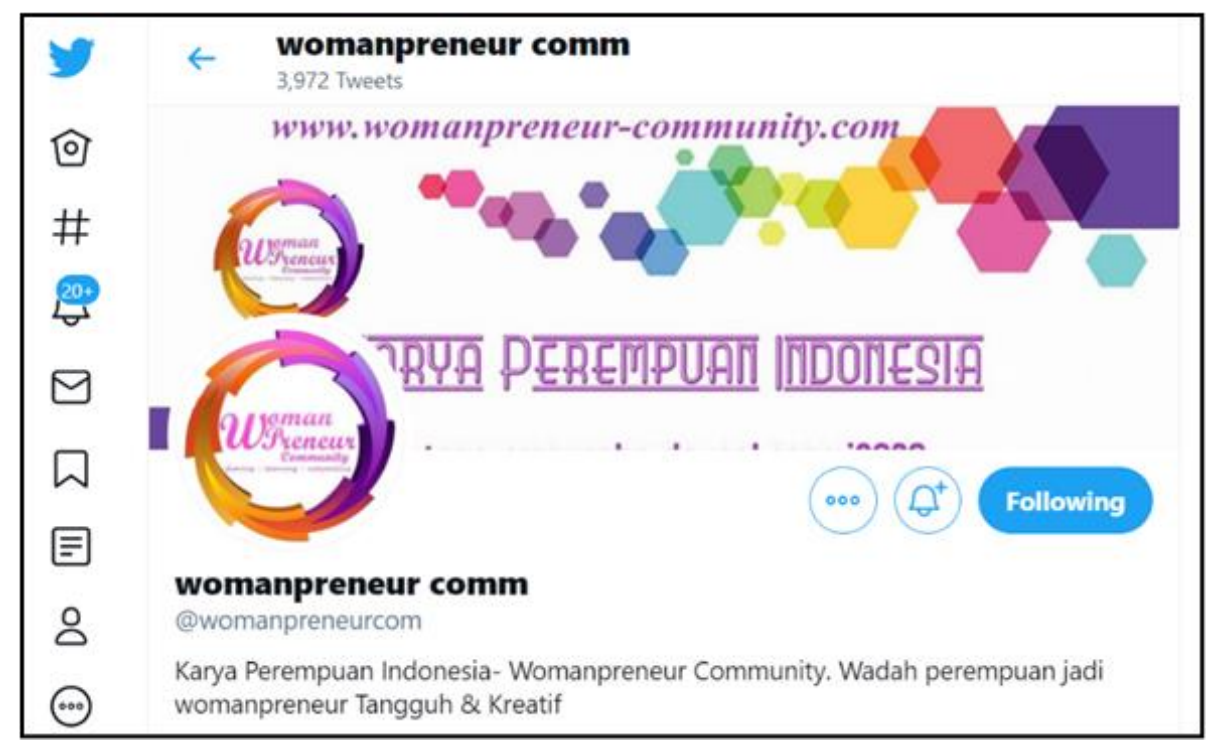

Fig. 3. Womanpreneurcom

The below research data in Table 1 is the result from the digital method approach where this data available for public access. This data is the basis of discussion in the study where it complements the explanation. This table is also an additional data which guides this study conclusion which will contribute to the study of social media and the concept of feminism and entrepreneur.

Table 1. Research Data

\begin{tabular}{|c|c|c|c|c|c|}
\hline ID & Bio & $\begin{array}{c}\text { Total } \\
\text { Follower }\end{array}$ & $\begin{array}{c}\text { Total } \\
\text { Tweets }\end{array}$ & $\begin{array}{c}\text { Joined } \\
\text { Twitter }\end{array}$ & Username \\
\hline $\begin{array}{l}10511569271 \\
64559360\end{array}$ & $\begin{array}{l}\text { Empowering Indonesia } \\
\text { Womenpreneur }\end{array}$ & 1105 & 126 & $\begin{array}{c}2018- \\
10-14 \\
00: 05\end{array}$ & womenpreneuridn \\
\hline 625248936 & $\begin{array}{l}\text { Karya Perempuan } \\
\text { Indonesia- } \\
\text { Womanpreneur } \\
\text { Community. Wadah } \\
\text { perempuan jadi } \\
\text { womanpreneur } \\
\text { Tangguh \& Kreatif }\end{array}$ & 822 & 3972 & $\begin{array}{c}2012- \\
07-03, \\
08: 55\end{array}$ & $\begin{array}{l}\text { womanpreneurco } \\
\mathrm{m}\end{array}$ \\
\hline 2527772322 & $\begin{array}{l}\text { walopun dasteran, } \\
\text { mendidik \& memantau } \\
\text { perkembangan anak, } \\
\text { sambil masak lauk } \\
\text { favorite keluarga tapi } \\
\text { INCOME teteup } \\
\text { mengalir DERAS, mau? }\end{array}$ & 145 & 124 & $\begin{array}{l}2014- \\
05-27, \\
23: 112\end{array}$ & DeDasterpreneur \\
\hline
\end{tabular}




\section{Conclusion}

To conclude, this study contributes to the argument that feminism does not need to be a resistance form within the society. This concept, especially in the eastern culture, does not need to be head-to-head rivalry with the opposite gender. The communication system from the data reveals that social media still a chosen communication channel where identity and attitude can be formed, in this case feminism. The concept of feminism found in this study especially exposed the gender equality. Women also have the equal opportunity in the area of entrepreneurship.

Communication in Twitter allow them to show identity using color scheme and message which encourage public especially their target audience to understand and eventually join their cause to be womenpreneur. The knowledge sharing also utilize in social media platform making the digital feminism popular among younger audiences [18].

\section{Acknowledgement} study.

Authors would like to thank Binus University for the support for the publication of this

\section{References}

[1] "Everyone Should Read These. Kamala Harris' Most Powerful Quotes." https://www.shethepeople.tv/news/kamala-harris-most-powerful-quotes/ (accessed Nov. 28, 2020).

[2] "For many Black women, Kamala Harris' victory means more than holding office." https://www.tampabay.com/news/florida-politics/elections/2020/11/26/for-many-black-womenkamala-harris-victory-means-more-than-holding-office/ (accessed Nov. 28, 2020).

[3] "Kamala Harris is more likely to think of a new paradigm for South Asia | The Indian Express." https://indianexpress.com/article/opinion/columns/kamala-harris-first-woman-us-vice-president7071058/ (accessed Nov. 28, 2020).

[4] "Activist Gloria Steinem says feminism has given us Vice President-elect Kamala Harris | Local News | omaha.com." https://omaha.com/news/local/activist-gloria-steinem-says-feminism-hasgiven-us-vice-president-elect-kamala-harris/article_665f8dbf-5ea6-5e67-90f1-3919180cfdcd.html (accessed Nov. 28, 2020).

[5] M. Kelly and G. Gauchat, "Feminist Identity, Feminist Politics: U.S. Feminists Attitudes toward Social Policies," Sociol. Perspect., vol. 59, no. 4, pp. 855-872, Dec. 2016, doi: $10.1177 / 0731121415594281$.

[6] M. E. John, "Feminism in india and the west recasting a relationship," Cult. Dyn., vol. 10, no. 2, pp. 197-209, 1998, doi: 10.1177/092137409801000207.

[7] E. Ikävalko and J. Kantola, "Feminist resistance and resistance to feminism in gender equality planning in Finland," Eur. J. Women's Stud., vol. 24, no. 3, pp. 233-248, Aug. 2017, doi: $10.1177 / 1350506817693868$.

[8] I. Fernandez-Mateo et al., "Bending the Pipeline? Executive Search and Gender Inequality in Hiring for Top Management Jobs Terms of Use Creative Commons Attribution-Noncommercial-Share Alike Bending the Pipeline? Executive Search and Gender Inequality in Hiring for Top Management Jobs,” Manage. Sci., vol. 62, no. 12, pp. 3636-3655, Dec. 2016, doi: 10.1287/mnsc.2015.2315. 
[9] A. Salam, "IJRTBT IMPACT OF DIGITIZATION ON WOMEN ENTREPRENEURS," 2018. $\begin{array}{lllll}\text { Accessed: } & \text { Nov. } & 28, & \text { Available: }\end{array}$ https://ejournal.lucp.net/index.php/ijrtbt/article/view/170.

[10] R. Rogers, Doing Digital Methods. Amsterdam: SAGE Publications Ltd, 2019.

[11] Y. Motoyama, S. Goetz, and Y. Han, "Where do entrepreneurs get information? An analysis of twitter-following patterns," J. Small Bus. Entrep., vol. 30, no. 3, pp. 253-274, May 2018, doi: 10.1080/08276331.2018.1435187.

[12] J. T. Yun, U. Pamuksuz, and B. R. L. Duff, "Are we who we follow? Computationally analyzing human personality and brand following on Twitter," Int. J. Advert., vol. 38, no. 5, pp. 776-795, Jul. 2019, doi: 10.1080/02650487.2019.1575106.

[13] T. Bosch and B. Mutsvairo, "Pictures, Protests and Politics: Mapping Twitter Images during South Africa's Fees Must Fall Campaign,” African Journal. Stud., vol. 38, no. 2, pp. 71-89, Apr. 2017, doi: 10.1080/23743670.2017.1368869.

[14] M. Tremayne, "Anatomy of Protest in the Digital Era: A Network Analysis of Twitter and Occupy Wall Street," Soc. Mov. Stud., vol. 13, no. 1, pp. 110-126, 2014, doi: 10.1080/14742837.2013.830969.

[15] R. Agrifoglio, S. Black, C. Metallo, and M. Ferrara, "Extrinsic versus intrinsic motivation in continued twitter usage," J. Comput. Inf. Syst., vol. 53, no. 1, pp. 33-41, Sep. 2012, doi: 10.1080/08874417.2012.11645594.

[16] W. Williamson and K. J. Ruming, "Live tweeting the planning reform workshop," Aust. Plan., vol. 55, no. 1, pp. 1-11, Jan. 2018, doi: 10.1080/07293682.2018.1494611.

[17] S. Gilbert, "Learning in a Twitter-based community of practice: an exploration of knowledge exchange as a motivation for participation in \#hcsmca," Inf. Commun. Soc., vol. 19, no. 9, pp. 1214 1232, Sep. 2016, doi: 10.1080/1369118X.2016.1186715.

[18] S. Jackson, "Young feminists, feminism and digital media," Fem. Psychol., vol. 28, no. 1, pp. 32 49, Feb. 2018, doi: 10.1177/0959353517716952. 